\title{
PASAR, WADAH STRATEGIS ZAKAT DAN AMAL SOSIAL
}

\author{
Amin Nasir \\ Sekolah Tinggi Agama Islam Negeri (STAIN) Kudus \\ e-mail: aminnasir93@gmail.com
}

\begin{abstract}
Zakah is one of the characteristics of the Islamic economic system, because zakah is one of the implementation of the principle of justice in the Islamic economic system. Trade is one form of legal business. The predominantly Muslim village of Mejobo has considerable potential associated with zakat, where the mejobo village has a prominent market commodity in the south of the southern part of the potential Brayung market in which a total of approximately 1000 traders in the Mejobo Village market. Materially the traders gain prosperity through two things: capital turnover and reasonable trade margin. However, in reality the merchants are distributing their zakah directly to mustahiq without going through zakah institution in the form of money every close to Eid al-Fitr. In addition, they also channel their zakah to a person who is not assigned as an amilin or zakah officer but to a person who is trusted to distribute. It is unfortunate if this large potential is not touched optimally by the zakah amil institutions in both the private and government. So it can be ascertained that the prospect of Brayung Desa Mejobo market must be developed maximally so that in addition to the obligation of Muslims to pay zakah, it also affects the social good and reduces the burden of the government.
\end{abstract}

Keywords: Zakah, Market, and Social Charity 


\section{Pendahuluan}

Islam mempunyai potensi untuk ikut berpartisipasi dalam pembangunan guna meningkatkan taraf hidup dan kesejahteraan masyarakat. Potensi yang dapat digali, dikembangkan, dan didayagunakan dalam penyediaan dan pembangunan di bidang sosial adalah dari pengumpulan dana zakat, infaq, dan sedekah.

Zakat adalah salah satu rukun Islam yang merupakan kewajiban Agama yang dibebankan atas harta kekayaan seseorang. Perkataan zakat disebut di dalam al-Qur'an sebanyak 82 kali dan selalu dirangkaikan dengan solat (sembahyang) yang merupakan rukun Islam kedua. Ini menunjukan pentingnya zakat itu, setelah solat yang merupakan sarana komunikasi utama antara manusia dengan Tuhan (Daud Ali, 2006:38). Hal ini sesuai dengan firman Allah dalam al-Quran surat At-Taubah ayat 103 yang artinya: "Ambillah zakat dari sebagian harta mereka, dengan zakat itu kamu membersihkandan mensucikan mereka dan mendoalah untuk mereka. Sesungguhnya doa kamu itu (menjadi) ketenteraman jiwa bagi mereka. dan Allah Maha mendengar lagi Maha mengetahui." (QS. At-Taubah: 103)

Dalam kitab-kitab hukum Islam, perkataan zakat itu diartikan dengan suci, tumbuh dan berkembang serta berkah, adapun tujuannya zakat dalam hubungan ini adalah sasaran praktisnya antara lain sebagai berikut (1) mengangkat derajat fakir miskin dan membantunya keluar dari kesulitan hidup dan penderitaan, (2) Membantu pemecahan permasalahan yang dihadapi oleh gharimin, ibnussabil, dan mustahik lainnya, (3) Membentangkan dan membina tali persaudaraan sesama umat Islam dan manusia pada umumnya, (4) menghilangkan sifat kikir dan atau loba pemilik harta, (5) Membersihkan sifat kikir dan iri dari hati orang-orang miskin, (6) menjembatani jurang pemisah antara yang kaya dan yang miskin dalam suatu masyarakat, (7) Mengembangkan rasa tanggung jawab sosial pada diri seseorang, terutama pada mereka yang mempunyai harta, (8) Sarana 
pemerataan pendapat (rezeki) untuk mencapai keadilan sosial (Daud Ali, 2006:40).

Dalam Undang-Undang Republik Indonesia Nomor 23 tahun 2011 tentang Pengelolaan Zakat, disebutkan Pasal 1 Pengelolaan zakat adalah kegiatan perencanaan, pelaksanaan dan pengorganisasian dalam mengumpulkan, mendistribusikan dan mendayagunakan zakat. selain itu dalam pasal 25 dan 26 zakat wajib didistribusikan kepada mustahik sesuai syariat Islam. Pendistribusian zakat dilakukan berdasarkan skala prioritas dengan memperhatikan prinsip pemerataan, keadilan dan kewilayahan.

Dalam Undang-Undang yang baru ini, BAZNAS diberikan wewenang sebagai pengelola zakat nasional, sekaligus yang berhak memverifikasi berdirinya LAZ. Dengan wewenang BAZNAS tersebut, pengumpulan dana zakat diharapkan bisa terorganisir secara efektif, dan dapat terdistribusikan secara efisien.

Manajemen dalam sebuah organisasi pengelola zakat akan menyangkut tiga unsur yang meliputi: manajemen pengumpulan, pendistribusian, dan pendayagunaan. Dari ketiga unsur tersebut manajemen pendistribusian merupakan tolak ukur bagi terbentuknya ekonomi masyarakat. Sebab pendistribusian didalamnya mengandung pendayagunaan dana zakat baik yang bersifat konsumtif maupun produktif. Dalam pendistribusian perlu adanya manajemen khusus yang mengelola tentang penyaluran zakat. Jika Badan Amil Zakat memprioritaskan pendistribusian zakat dengan kegiatan yang bersifat produktif, niscaya pemberdayaan ekonomi masyarakat untuk merubah strata kaum dhuafa akan terwujud.

Oleh karena itu manajemen pendistribusian zakat perlu diimplementasikan pada sebuah organisasi pengelola zakat. Dalam hal ini Badan Amil Zakat Nasional Kabupaten merupakan BAZNAS yang paling sentral dan diharapkan bisa mengoptimalkan pengelolaann dalam pendistribusiannya. Namun sampai saat ini lemahnya pola kordinasi dalam implementasi 
pengelolaan zakat baik intra maupun mitra BAZNAS, begitupun dengan pendistribusiannya masih kurangnya pola dan manajemen pendistribusian dalam mendayagunakan dana zakat. Berdasarkan uraian tersebut, maka artikel ini akan mengkaji lebih jauh bagaimana mengoptimalkan pengelolaan zakat dan amal sosial melalui pasar.

\section{Pembahasan}

\section{Pengelolaan Zakat}

Dalam pengelolaan zakat tidak boleh lepas dari sandarannya yang utama sebagai dalil pengelolaan yaitu alQuran dan Hadis. Di antara dalil tersebut adalah ayat 60 surat AtTaubah yang artinya: "Sesungguhnya zakat-zakat itu, hanyalah untuk orang-orang fakir, orang-orang miskin, pengurus-pengurus zakat, Para mu'allaf yang dibujuk hatinya, untuk (memerdekakan) budak, orangorang yang berhutang, untuk jalan Allah dan untuk mereka yuang sedang dalam perjalanan, sebagai suatu ketetapan yang diwajibkan Allah, dan Allah Maha mengetahui lagi Maha Bijaksana." (QS. AtTaubah: 60)

Menurut Masdar Mas'udi,sasaran distribusi zakat disebutkan dalam al-Quran surat at-Taubah ayat 60. Dalam ayat tersebut ada 8 kelompok sasaran pendistribusian zakat yaitu fakir, miskin, amil, mu'allaf, membebaskan budak (riqab), orang yang berutang (gharim), fi sabilillah, dan ibnu sabil (Masdar Mas'udi, 1991). Berikut dijelaskan masing-masing golongan penerima zakat dan penafsirannya sesuai dengan konteks sekarang;

Pertama dan kedua, Fakir dan Miskin. Pada umumnya para fuqaha menetapkan kebutuhan pokok hanya dalam tiga hal yaitu pangan, sandang, dan papan, dan kebutuhan tersebut sangat minimalis atau sekedar untuk bertahan hidup.Untuk konteks sekarang, konsep kebutuhan pokok seperti itu jelas perlu penyesuaian. Bukan saja kuantitasnya tetapi juga kualitasnya sehigga dengan kebutuhan pokok tersebut manusia bisa hidup secara wajar (Masdar Mas'udi, 1991:149). Bedanya, kelompok 
fakir keadaanya lebih kurang beruntung dibanding dengan kelompok miskin.

Ketentuan kebutuhan pokok tersebut adalah; pangan dengan kandungan kalori dan protein yag memungkinkan pertumbuhan fisik secara wajar; sandang yang dapat menutupi aurat dan melindungi gangguan cuaca; papan yang dapat memenuhi kebutuhan berlindung dan membina kehidupan keluarga secara layak; dan pendidikan yang memungkinkan pihak bersangkutan mengembangkan tiga potensi dasarnya selaku manusia: kognitif, afektif, dan psikomotorik.

Dengan demikian, dana zakat dapat digunakan untuk pembangunan sarana dan prasarana pertanian sebagai tumpuan kesejahteraan ekonomi rakyat dan pengairan yang luas, pembangunan sektor industri yang secara langsung berorientasi pada peningkatan kesejahteraan rakyat banyak. Di samping itu, dana zakat juga dapat digunakan untuk pengadaan sarana dan prasarana pendidikan dasar sampai tinggi untuk setiap warga yang memerlukan, pengadaan sarana dan prasarana kesehatan bagi rakyat, dan pengadaan sarana dan prasarana lain yang erat hubungannya dengan usaha menyejahterakan rakyat yang berada pada atau di bawah garis kemiskinan.

Ketiga, Amilin. Dalam literatur-literatur fiqh yang disebut dengan amil zakat adalah imam, khalifah atau amir. Hal ini menunjukkan bahwa yang disebut amil adalah instasi pemerintah yang bertugas secara khusus untuk memungut dan mengelola zakat.

Dengan demikian, apabila dikaitkan dengan hak penerimaan dana zakat, yang disebut amil adalah orang-orang dan atau fungsi-fungsi yang terlibat dalam salah satu dari bidang tanggung jawab yaitu; aparat pemungut atau pencatat zakat, aparat administrasi perzakatan, segenap aparat departemen teknis yang bekerja untuk kesejahteraan rakyat dengan dana zakat (Mas'udi, 1991:151). 
Semua orang yang terlibat dalam salah satu dari empat tugas tersebut berhak menerima bagian dari dana zakat dalam ukuran yang disepakati.

Keempat, Muallaf. Secara harfiah "muallafati qulubuhum" dalam ayat 60 surat at-Taubahberarti orang yang sedang dijinakkan harinya. Dengan meminjam ijtihad Umar, pembujukan hati tersebut bukan semata bertujuan agar mereka tetap masuk dalam komunitas Muslim, tetapi lebih agar mereka memilih jalan hidup sesuai dengan jalan hidup kaum Muslim yang sebenarnya, yaitu jalan hidup yang sesuai dengan fitrah manusia.

Dengan pengertian ini, maka dana zakat dapat digunakan untuk menyadarkan kembali anggota masyarakat yang terperosok ke jalan hidup yang berlawanan dengan fitrah kemanusiaan seperti penyalahgunaan narkotika dan sejenisnya.

Kelima, Riqab (Budak). Secara bahasa, Riqabadalah orang dengan status budak. Untuk masa sekarang, manusia dengan status budak belian seperti ini sudah tidak ada lagi. Tetapi, apabila dilihat maknanya secara lebih dalam, arti Riqabmerujuk pada kelompok manusia yang tertindas dan dieksploitasi oleh manusia lain, baik secara personal maupun struktural.

Dengan pengertian ini, dana zakat untuk kategori Riqabdapat digunakan untuk "memerdekakan" orang atau kelompok masyarakat yang sedang dalam keadaan tertindas dan kehilangan haknya untuk menentukan arah hidupnya sendiri. Dengan demikian, dana zakat dapat digunakan untuk membantu buruh-buruh rendahan dan kuli-kuli kasar dari hegemoni majikan mereka dan lain-lain (Masdar Mas'udi, 1991:156).

Keenam, Gharimin. Secara bahasa, "Gharimin" adalah orangorang yang tertindih hutang. Untuk konteks sekarang, pengertian ini masih relevan. Tetapi, di samping penggunaan dana zakat yang bersifat kreatif atau memberikan bantuan setelah terjadinya kebangkrutan atau kepailitan orang yang berutang tersebut, dana zakat seharusnya juga dapat digunakan untuk mencegah 
terjadinya kebangkrutan tersebut dengan menyuntikkan dana agar usaha seseorang yang terancam bangkrut dapat pulih kembali.

Ketujuh, Fi sabilillah. Menurut Masdar Mas'udi (1991:159), istilah "fi sabilillah" memiliki dua pengertian. Dalam pengertian negatif, fi sabilillah berarti berperang memerangi kekafiran. Sedangkan menurut pengertian positif, fi sabilillah berarti menegakkan "jalan Allah" itu sendiri. Jalan Allah itu diartikan sebagai "cita kebaikan-kebaikan-Nya yang universal, yang mengatasi batas kepercayaan, suku, ras, dan batas-batas formal lainnya.Rinciannya bisa macam-macam, tetapi pangkalnya adalah kemaslahatan bersama.

Kedelapan, Ibnu Sabil. Para ahli Fiqh selama ini mengartikan Ibnu Sabilsebagai "musafir yang kehabisan bekal". Meskipun tidak salah dan masih relevan, namun pengertian ini sangat sempit. Untuk konteks sekarang, pengertian Ibnu Sabildapat dikembangkan bukan sekedar pada "pelancong" yang kehabisan bekal, tetapi juga terhadap orang atau kelompok masyarakat yang "terpaksa" menanggung kerugian atau kemalangan ekonomi karena sesuatu yang tidak disengaja seperti karena bencana alam, wabah penyakit, dan peperangan.

Dengan pengertian tersebut, maka dana zakat dapat digunakan tidak saja untuk keperluan musafir yang kehabisan bekal, tetapi juga untuk keperluan pengungsi baik karena alasan politik maupun karena alasan lingkungan alam seperti banjir, tanah longsor, kebakaran, dan sebagainya.

Dalil yang kedua untuk pengelollan zakat adalah hadis Nabi yang diriwayatkan oleh Imam Bukhari dan Imam Muslim dari Ibnu Abbas yang artinya:Dari Ibnu Abbas, bahwa Nabi SAW mengutus Mu'adz ke negeri Yaman (ia meneruskan hadits itu) dan di dalamnya (beliau bersabda): Sesungguhnya Allah telah mewajibkan mereka zakat dari harta mereka yang diambil dari orang-orang kaya di antara mereka dan dibagikan kepada orang-orang fakir di antara mereka."(HR. Bukhari Muslim) 


\section{Optimalisasi pengelolaan zakat di pasar Brayung Mejobo}

Pasar Brayung merupakan salah satu pasar terbesar di wilayah Kudus timur dan merupakan sentra perdagangan yang ramai baik siang maupun malam, namun waktu malam lebih ramai daripada siang sehingga bisa disebut dengan kehidupan malam. Lokasinya berada di desa Mejobo kecamatan Mejobo Kudus, dari bangjo Jepang jalan lingkar selatan ke arah timur sekitar 4 kilometer, bisa juga lewat jalan lingkar timur Ngembal ke arah selatan desa Tenggeles sekitar 2 kilometer. Letaknya berada tepat di barat perempatan Brayung.

Kehidupan malam yang dimaksud di atas bukanlah kehidupan malam yang berhubungan dengan dunia hiburan dan gemerlap malam dalam arti konotasi, namun menjelaskan tentang keramaian pasar Brayung saat malam hari. Pasar Brayung memang merupakan salah satu pasar di Kudus yang buka hingga malam hari dan sangatlah ramai dikunjungi masyarakat yang ingin membeli sesuatu maupun yang sekedar ingin jalan-jalan dan mencari makan.

Mengapa pasar Brayung begitu sangat ramai di tiap hari, sangat sederhana, karena pasar ini berada di tengah-tengah wilayah strategis yang dikelilingi oleh banyak desa, antara lain desa Mejobo, Jepang, Temulus, Kesambi, Hadiwarno, Tenggeles, Jojo, Sadang, dan Bulung. Begitu banyak masyarakat desa tersebut yang setiap malam ke pasar Brayung ini, bahkan dari luar desa pun banyak yang datang.

Selain letaknya yang strategis, faktor yang membuat pasar ini ramai adalah banyaknya dagangan yang dijual di sini. Pada pagi hari, pasar ini menjual sembako, pakaian, sayur mayur, buah buahan dan sebagainya dengan konsumen kebanyakan ibu-ibu. Pemandangan berbeda akan terlihat pada malam hari, pasar ini banyak menjual pakaian, sandal, sepatu, aneka macam jajanan seperti sosis, kojek bakar, kojek kuah, roti bakar, nasi goreng, ayam bakar dan goreng serta berbagai macam permainan anakanak. Pada malam hari rata-rata pengunjung adalah muda mudi, anak-anak maupun orang tua. 
Harga yang murah membuat pasar Brayung menjadi destinasi belanja masyarakat. Semua barang tersedia di pasar Brayung, bahkan bisa dibilang semua ada di sini. Keramaian di pasar Brayung saat malam hari sangat terasa. Semuamasyarakat sekitar berbondong-bondong ke tempat ini. Pasar malam di Brayung buka dari sore hingga malam hari.

Keberadaan manajemen di pasar Brayung juga mempengaruhi stabilitas yang ada didalam masyarakat pasar tersebut, karena adanya tuntutan pengaturan dalam kehidupan masyarakat, kebutuhan negara menjalankan fungsi dan tanggung jawab terhadap rakyat dan aspek-aspek kehidupan yang lain. Menurut Hafidhuddin dan Henri Tanjung (2003:19), apabila kita membicarakan manajemen, maka perlu kita menyadari bahwa manajemen telah begitu ada dalam kehidupan ini.

Menurut Kast dan James E Rosenzweig dalam Ismail Nawawi (2010:46) manajemen adalah pekerjaan mental (pikiran intuisi, perasaan) yang dilaksanakan oleh orang-orang dalam konteks organisasi. Manajemen adalah sub sistem kunci dalam sistem organisasi dan merupakan kekuatan vital yang menghubungkan semua sistem lainnya. Manajemen mencakup hal-hal sebagai berikut:

1. Mengkoordinasikan sumber daya manusia, material dan keuangan kearah tercapainya organisasi secara efektif dan efisien

2. Menghubungkan organisasi dengan lingkungan luar dan menanggapi kebutuhan masyarakat

3. Mengembangkan iklim organisasi dimana orang dapat mengejar sasaran perseorangan (Individual) dan sasaran bersama (collective)

4. Melaksanakan fungsi tertentu yang dapat ditetapkan seperti menentkan sasaran, merencanakan merakit sumber daya, mengorganisir, melaksanakan, dan mengawasi

5. Melaksanakan berbagai peranan antar pribadi informasional dan memutuskan (decisional). 
Berkaitan dengan manajemen zakat yang ada di pasar Brayung Mejobo ini dengan kerangka pemikiran sebagaimana diatas harus berpedoman dengan prinsip-prinsip dasar manajemen secara professional sebagaimana penerapan ketentuan-ketentuan atau prinsip dan fungsi manajemen secara umum. Secara operasional dan fungsional manajemen zakat dijelaskan secaara terperinci yang berkaitan dengan perencanaan, pengorganisasian, pelaksanaan, dan pengawasan yang berkaitan dengan zakat (Ismail Nawawi, 2010:47).

\section{Perencanaan zakat}

Secara konseptual perencanaan adalah proses pemikiran penentuan sasaran dan tujuan yang ingin dicapai, tindakan yang harus dilaksanakan, bentuk organisasi yang tetap ntuk mencapainya dan orang-orang yang bertanggung jawab terhadap kegiatan yang hendak dilaksanakan oleh badan/lembaga amil zakat (Ismail Nawawi, 2010:48). Yang dilakukan di pasar brayung adanya acara setiap tahun sekali dengan mengumpulkan zakat mereka serta menyantuni anak-anak yatim dan pengajian akbar yang uang yang terkempul didistribusikan sesuai yang berhak menerimanya.

Terkait dengan perencanaan zakat Ismail Nawawi (2010:48) menguraikan kegiatan dengan proses sebagai berikut:

1. Menetapkan sasaran dan tujuan zakat. sasaran zakat berkaitan dengan orang yang berkewajiban zakat (muzzaki) dan orang yang berhak mendapatkan zakat (mustahiq). Sedangkan tujuan adalah menyantuni orang yang berhak agar terpenuhi kebutuhan dasarnya atau meringankan beban mereka dalam hal ini masyarakat mejobo dan desa yang berdekatan yang dapat santunan yang di pelopori $\mathrm{H}$ Safi'i oleh warga Kirig

2. Menentukan waktu untuk penggalian sumber zakat dan waktu untuk mendistribusikan zakat dengan skala prioritas yang terjadi di pasar brayung adalah setiap tahun dengan asumsi tahun baru hijriyah. 
3. Menetapkan amil atau pengelola zakat dengan menentukan orang yang mempunyai komitmen, kompetensi, mindset dan profesionalisme untuk pengelolaan zakat.

4. Menetapkan sistem pengawasan terhadap pelaksanaan zakat, baik mulai dari pembuatan perencanaan, pembuatan pelaksanaan, pengembangan terus menerus secara berkesinambungan.

Dari perencanaan tersebut, kemudian dibuatlah program kerja yang sesuai dengan tuntutan dan kebutuhan kelembagaan zakat yang telah ditetapkan. Tugas utama dalam merancang bangun kegiatan zakat harus disesuaikan dengan lingkungan kerjanya agar dapat membantu menciptakan efisiensi, efektivitas dan dilakukan secara rasional (Ismail Nawawi, 2010:49).

\section{Pendistribusian dan pengembangan zakat}

Distribusi zakat dapat dilakukan dengan dua pola yaitu dengan pola memberikan kepada orang yang berhak menerima (mustahik)secara komsumtif dan dapat diberikan dengan cara produktif atau dengan cara memberikan modal atau zakat dapat dikembangkan dengan pola investasi (Ismail Nawawi, 2010:67).

Sebagai mana telah disebutkan, zakat dapat diberikan secara konsuntif dan dapat diberikan secara produktif. Adapun penyaluran secara produktif sebagaimana yang pernah terjadi di zaman Rasulullah SAW yang dikemukakan dalam sebuah hadis riwayat Muslim dari Salim bin Abdillah bin Umar dari ayahnya, bahwa Rasulullah telah memberikan kepadanya zakat lalu menyuruhnya untuk dikembangkan atau disedekahkan lagi (Ismail Nawawi, 2010:76).

Dalam kaitan dengan pemberian zakat yang bersifat produktif, terdapat pendapat yang menarik sebagaimana dikemukakan oleh Yusuf al-Qardhawi dalam Figh Zakatbahwa pemerintah Islam diperbolehkan membangun pabrik-pabrik atau perusahaan-perusahaan dari uang zakat untuk kemudian kepemilikan dan keuntungannya bagi kepentingan fakir miskin, 
sehingga akan terpenuhi kebutuhan hidup mereka sepanjang masa (Ismail Nawawi, 2010:76).

Oleh karena rakyat Indonesia masih banyak yang hidup dibawah garis kemiskinan, maka masalah kebodohan dan kesempatan memperoleh pendidikan masih merupakan masalah serius yang harus dipecahkan. Pemberdayaan zakat dalam rangka memperbaiki taraf hidup dapat diberikan kepada:

Pertama, Petani Kecil dan Buruh Tani, untuk meningkatkan taraf hidup mereka, usaha yang dapat dilakukan yaitu memberikan pengetahuan tentang home industri. Tentang home industri apa yang harus disesuaikan dengan lingkungan masyarakatnya. Maksudnya dengan pengetahuan itu diharapkan mereka dapat menciptakan usaha yang dapat menambah penghasilan. Kedua, memberikan modal baik berupa uang (untuk usaha) atau diberikan ternak kambing, sapi, kerbau dan lain sebagainya.

Kedua, Pedagang atau Pengusaha Kecil. Memberikan pengetahuan tentang sistem manajemen, bimbingan atau penyuluhan, sehingga mereka akan mampu mengelola usahanya dengan baik. Selanjutnya memberikan pinjaman modal untuk dapat mengembangkan usahanya.

Disamping itu, zakat dapat digunakan untuk mengatasi ketenagakerjaan atau Pengangguran. Hal ini seperti digunakan untuk usaha mengurang kemiskinan.Usaha menanggulangi pengangguran atau memecahkan persoalan angkatan kerja itu dapat dilakukan:

1. Kegiatan yang sifatnya memberikan motivasi untuk berwirausaha kepada para angkatan kerja dengan memberikan pengetahuan tentang berbagai macam keterampilan, seperti jahit-menjahit pertukangan dan lain sebagainya

2. Kegiatan yang sifatnya memberikan motivasi untuk berniaga, dengan memberikan pengetahuan tentang usaha dagang. 
3. Memberikan permodalan untuk menindak lanjuti kegiatan-kegiatan di atas.

\section{Pendayagunaan zakat}

Usaha pendayagunaan zakat juga harus digalakkan agar dana zakat terkumpul dengan baik, yaitu dengan cara:

1. Memberikan motivasi kepada wajib zakat sehingga tumbuh kesadaran untuk menunaikan kewajibannya dengan memberikan penjelasan untuk apa zakat tersebut akan dimanfaatkan

2. Pembinaan mustahik (seperti memberikan atau membekali mereka dengan pengetahuan-pengetahuan yang sangat berguna).

Untuk mengurangi kebodohan, dana zakat dapat digunakan untuk pendidikan dan beasiswa. Dalam hal ini program-program yang dapat dilakukan pada pokoknya dapat dibedakan menjadi dua;pertama, memberikan bantuan kepada organisasi atau yayasan yang bergerak dalam bidang pendidikan baik berupa uang atau sarana pendidikan yang mendesak untuk segera disediakan. Kedua, memberikan bantuan biaya sekolah kepada anak-anak tertentu atau sifatnya tetap dalam beasiswa kepada beberapa anak, sehingga ia dapat melanjutkan sekolah atau belajar sampai jenjang tertentu yang ditetapkan oleh pengelola atau pengusrus BAZNAS.

Usaha lain untuk pendayagunaan zakat adalah membuat proyek kesehatan. Kegiatan yang dapat dilakukan diantaranya adalah mendirikan poliklinik, hal ini di daerah perkotaan telah banyak dilakukan, tetapi apabila dirintis di daerah pedesaan tentunya akan sangat besar perannya bagi pelayanan kesehatan untuk masyarakat kecil.

Pendistribusian zakat secara produktif, disamping berpedoman dari hadis yang disampaikan oleh RAsulullah SAW sebagaimana diatas, juga berpedoman terhadap pendapat para 
ahli tafsir, hadis dan pendapat para ahli fiqh. Para ahli tafsir memberikan penafsiran terhadap ayat 60 surat At-Taubah yang berkaitan dengan fi Sabilillah. Dalam Tafsir al-Maraghi disebutkan, bahwa yang dimaksud FiSabilillah adalah jalan yang ditempuh menuju ridha Allah, yaitu orang-orang yang berperang dan petugas-petugas yang menjaga perbatasan.Oleh Imam Ahmad diperluas lagi pengertiannya, yaitu menyantuni para Jemaah haji, karena melaksanakan ibadah haji itu termasuk berjuang dijalan Allah.

Demikian pula termasuk ke dalam pengertian Fi Sabilillah semua bentuk kebaikan seperti mengkafani orang yang meninggl dunia, membuat jembatan, membuat benteng pertahanan dan memakmurkan masjid dalam pengertian yang luas seperti membangun dan memugar masjid. Kalau dikaitkan dengan perang, maka cakupannya lebih luas lagi, yaitu menyangkut dengan persenjataan dan sarana-sarana lainnya yang dilakukan selama peperangan (Nawawi Ismail, 2010:77).

\section{Pemberdayaan kemiskinan melalui zakat}

Dalam beberapa ayat dalam al-Quran ditemukan, agar nasib orang fakir dan orang miskin itu diperhatikan benar, karena itulah di antara misi agama Allah itu diturunkan ke atas dunia ini. Orang fakir yang sengsara harus diperhatikan. Kefakiran itu perlu diperangi dan dihilangkan, karena bisa merusak iman (akidah).

Dalam pemberdayaan kemiskinan menurut Ismail Nawawi (2010:82) jalan yang dapat ditempuh ada dua cara yaitu:

1. Menyantuni mereka dengan memberikan dana (zakat) yang sifatnya konsumtif, atau dengan cara,

2. Memberikan modal yang sifatnya produktif, untuk diolah dan dikembangan. Sebenarnnya, bila kita memperhatikan keadaan fakir miskin, maka tetap ada zakat konsumtif, walaupun ada kemungkinan melaksanakan zakat produktif. 
Pemberian modal kepada perorangan harus dipertimbangkan dengan matang oleh Amil. Apakah mampu orang tersebut mengolah dana yang diberikan itu, sehngga pada satu saat dia tidak lagi menggantungkan hidupnya kepada orang lain, termasuk mengharapkan zakat. Apabila hal ini dapat dikelola dengan baik atas pengawasan dari Amil (bila memungkinkan) maka secara berangsur-angsur, orang yang tidak punya menjdi Muzakki (pemberi zakat), bukan lagi sebagai penerima.

Sekiranya usaha itu dikelola secara kolektif, maka orangorang fakir miskin yang mampu bekerja menurut keahliannya (keterampilan) masing-masing, mesti diikursertakan. Dengan demikian jaminan (biaya) sehari-hari dapat diambil dari usaha bersama itu. Apabila usaha itu berhasil (beruntung), maka mereka menikmati bersama juga hasilnya itu. Hal ini tentu memrlukan manajemen yang teratur rapid an sebagai pimpinannya dapat ditunjuk dari kalangan orang-orang yang tidak mampu itu (fakir miskin) atau ditunjuk orang lain yang ikhlas beramal membantu mereka. Apabila persoalan ini ditangani dengan sungguhsungguh, kita optimis akan keberhasilannya kendatipun mereka belum dapat sebagai muzakki, tetapi sekuraang-kurangnya idak menjadi bebrakan lagi bagi anggota masyarakat (Ismail Nawawi, 2010:83).

\section{Simpulan}

Berdasarkan pembahasan di atas dapat ditarik kesimpulan bahwa masyarakat Mejobodalam membayar zakat sangat beragam sekali ketika moment tepat dan ada fasilitas mereka berbondongbondong membayar zakat hal ini juga disesuaikan acara dan panitia pengelola zakat di pasar Brayung. Dan berdasarkan analisis faktor, terdapat beberapa faktor yang mempengaruhi masyarakat pasar Brayung Mejobo dalam membayar zakat, yakni tingkat pemahaman tentang zakat, tingkat kepedulian sosial, faktor respon terhadap pengaruh membayar zakat bagi muzakki, ketersediaan informasi tentang zakat, serta faktor layanan dan lokasi Organisasi Pengelola Zakat. 
Tingkat pemahaman masyarakat dalam membayar zakat relatif "Sangat Baik" meskipun sebagian kecil masyarakat kurang paham terhadap jenis zakat yang dibayar. Dan kepuasan masyarakat terhadap layanan Organisai Pengelola Zakat masih relatif baik juga baik pedagang dikumpulkan di beri arahan memalui selebaran dan kemudian membayar dan panitia pengelola mendistribusikan sesuai moment dan acara yang disepakati.

\section{DAFTAR PUSTAKA}

Abdul Sami Al-Mishri, Pilar-Pilar Ekonomi Islam, Pustaka Pelajar, Yogyakarta, 2006.

Abdurrachman Qadir, Zakat dalam Dimensi Mahdhah dan Sosial, Cet. 2, PT. Raja Grafindo Persada, Jakarta, 2001.

Afzalur Rahman, Doktrin Ekonomi Islam, Jilid III, PT. Dana Bhakti Wakaf, Yogjakarta, 1996.

Ahmad Rofiq, Figh Kontekstual Dari Normatif Ke Pemaknaan Sosial, Pustaka Pelajar, Semarang, 2004.

Masdar Farid Mas'udi, dkk., Reinterprestasi Pendayagunaan ZIS Menuju Efektivitas Pemanfaatan Zakat Infaq Sedekah, Piramedia, Jakarta, 2004.

Mohammad Daud Ali, Sistem Ekonomi Islam: Zakat \& Wakaf, UI Press, Jakarta, 1988.

Muhammad Ridwan, Manajemen Baitul Maal Wa Tamwil, UII Press, Yogyakarta,2004.

Mursyidi, Akuntansi dan Zakat Kontemporer, PT. Remaja Rosdyakarya, Bandung,2006.

Nuruddin Muhammad Ali, Zakat, sebagai Instrumen dalam Kebijakan Fiskal, PT RajaGrafindo Persada, Jakarta, 2006.

Wahbah Al-Zuhayly, Zakat, Kajian Berbagai Mazhab, PT Remaja Rosdakarya, Bandung 1995.

Yusuf al-Qardawi, Hukum Zakat, Cet. 10, PT. Mitra Kerjaya Indonesia, Jakarta, 2007. 